'Melarsen', 'Stilbamidine' and 'Butarsen', respectively. Experiments were also started on the possibility of forming suramin complexes with veterinary trypanocidal drugs, and basic research continued into the optimal conditions for rearing $G$. palpalis in the laboratory. In Northern Rhodesia studies were made of cross-resistance to drugs in trypanosomes occurring in cases treated with 'Dimidium', 'Ethidium' and Antrycide', and of the control of tsetses with insecticidal sprays, while in Uganda the Tsetse Control Department has obtained promising results in preliminary trials of 'Arkotine' for control of G. palpalis.

The report for $1955-56$ on locust research and control of the Director of the Anti-Locust Research
Centre, which received 1,171 reports from 42 territories in 1955, records further progress in the analysis of the seasonal development of desert locust plagues, and in the re-examination, in the light of recent information on swarm movements and behaviour, of the historical data on the ter-plague periods. The results suggest the possibility that some swarming populations occurring within the desert locust distribution area during the interplague periods may sometimes play an important part in the recrudescence of the plagues. In the locust laboratory the main emphasis has been on breeding Schistocerca. The Desert Locust Survey continued intensive investigations on the assessment and improvement of control methods, particularly aircraft spraying.

\title{
OBITUARIES
}

\section{Dr. G. B. Jeffery, F.R.S.}

GEORGE BARKer JEFFERY, director of the Institute of Education, University of London, who died on April 27, was born on May 9, 1891. He was educated at Wilson's Grammar School and went from there in 1909 to University College, London, where he rapidly made his reputation as a mathematician. $\mathrm{He}$ was appointed reader in mathematics in 1921 and Astor professor of mathematics in 1924; he was elected a Fellow of University College in 1916 and a Fellow of the Royal Society in 1926.

As this record implies, Jeffery's original work in mathematics began early (his first paper was read before the Royal Society in the month following his twenty-first birthday) and was distinguished. $\mathrm{He}$ covered a wide field in which the main subjects were the theory of relativity and (over a longer period) hydrodynamics and elasticity together with the theory of the relevant differential equations. His sustained interest in pure mathematics was evident, but the usual classification would assign most of his published work to applied mathematics. Much of his work was, however, concerned with exact solutions, and so was of particular value in fields where such solutions are rare and some form of approximation must often be accepted.

An inspiring teacher himself, Jeffery was interested in teaching in schools as well as in universities, in teaching overseas as well as at home ; this determined his choice of subject in various public addresses. In his presidential address to the London Mathematical Society (1937) his subject was the study of mathematies in modern universities. He said then that, if asked to say why he thought his own subject important, he might reply that "pure mathematics is a good subject because I like it", and suggested that all the implications of this answer should be fully thought out. In his presidential address in 1948 to the Mathematical Association on "Mathematics as an Educational Experience", he was concerned to defend mathematics as a school subject from "attack by the anti-intellectual forces that are rampant in our national educational thought". The imperfections in examinations were admitted, but "it would be idle to deny the stern discipline they effect by discriminating between sound knowledge and verbiage and between conscientious preparation and slacking".
It is perhaps natural that Jeffery, whose interests in mathematics were so wide, should have had wide interests outside, but it is astonishing that he should have found so much time and energy to devote to them. He was a skilled cabinet-maker, and excellent examples of his craft adorn University College, and no doubt other institutions with which he was concerned, and in later years he became a proficient silversmith. Since 1952 he had been dean of the College of Handicraft, and tribute has been paid to his enthusiasm by the master of the College, Mr. R. A. Butler.

In 1939 Jeffery acted as pro-provost for the section of University College that went to Bangor. He was occupied there with the difficult administrative problems of the war years as they affected the College and the University-and took part when occasion required in the rescue of parties of students in difficulties on Snowdon. He was appointed director of the Institute of Education shortly after the return in December 1944 of University College to London.

W. R. DEan

DR. G. B. JEFFERY first came into contact with the study of education and with the training of teachers when he was himself a student in 1911-12 at the old London Day Training College. It was there that he met his future wife; and it was there that he came under the influence of that great educator, Sir Percy Nunn. From the latter he acquired not only a deep interest in the philosophy of science and in the theory of education, but also an abiding faith in education as an instrument for social advance.

During the 'thirties, Prof. Jeffery was examiner in mathematics for several of the training colleges already associated with the University of London through the old Training Colleges Delegacy. Inevitably, his wisdom and his administrative gifts brought him into close contact with the running of that Delegacy : his counsel and advice were sought continually. Thus, when it became necessary, in 1945 , to work out the institutional mechanism needed to implement the McNair Report, it was to Jeffery that everyone turned. It was he who, more than anyone else, was responsible for drawing up a constitution and a set of regulations which are the charter of the London Area 'Training Organization. 